\title{
Entrepreneurial Orientation in Public Schools: The View from New Jersey
}

Steven E. Phelan

Ane T. Johnson

Thorsten Semrau

$W$ e utilize a sample of New Jersey schools to explore the relationship between entrepreneurial orientation (EO) and school performance. The results indicate a significant relationship between several dimensions of EO and performance after controlling for a number of relevant variables. Charter schools were found to have higher EO than traditional schools. The implications of these findings for education and entrepreneurship research are discussed.

Keywords: entrepreneurial orientation; education; performance; charter schools; policy

Over the last 20 years, educational policy in the United States has attempted to introduce more competition into the public education system (Ball, 1998; Burch, 2009; Lubienski, 2005; Power \& Frandji, 2010). Supporters of such measures have argued that allowing consumers to choose where to spend their educational dollars spurs schools to become more innovative, thereby improving student outcomes (Hoxby, 2003a). To date, the evidence linking competition to improved student achievement has been decidedly mixed, not least because of the heterogeneity in programs across local and state boundaries and the paucity of quality data (Teasley, 2009).

Previous research suggests that organizations that exhibit an entrepreneurial orientation (EO) tend to perform better than their peers and that the effect is particularly pronounced in more competitive environments (Lumpkin \& Dess, 1996; Miller, 1983). While originally applied to for-profit organizations, studies of EO have recently been extended to nonprofit organizations, such as hospitals and religious organizations, after appropriate modifications for the unique aspects of the nonprofit context (Bhuian, Menguc, \& Bell, 2005; Morris, Webb, \& Franklin, 2011; Pearce, Fritz, \& Davis, 2010). These studies have also found a positive relationship between $\mathrm{EO}$ and performance.

Introducing more competition between schools presupposes that schools are able to respond to the challenges in innovative and creative ways. In reality, there is likely to be heterogeneity among schools in their level of entrepreneurial orientation, with the more entrepreneurially minded schools likely to perform better. In this article we seek to test this intuition. The next section provides the background for the research, provides justification for its importance, and situates the hypotheses and research questions within the wider context of education and entrepreneurship. The article then goes on to outline the development of an EO scale for schools and presents the results of testing in New Jersey schools. The article concludes by examining the implications of the current research for scholarship, policy, practice, and society.

\section{Background}

In 1983, the Reagan administration released a report entitled "A Nation at Risk," which created a crisis atmosphere by arguing that the quality of education in the United States had declined precipitously from earlier years and that the nation was slipping in international comparisons as well (National Commission on Excellence in Education, 1983). Although the statistics in the report have subsequently been questioned, the perception that schools are underachieving has remained and has had a profound effect on educational policy.

\section{Accountability}

The No Child Left Behind (NCLB) Act, introduced by the Bush administration in 2002, is a key part of the reform movement in public education. The NCLB act mandates that schools report their performance on statewide, standardized tests to receive federal funding. Penalties are applied to schools with scores that fall below state targets. The penalties are meant to incentivize school personnel to improve their efforts over time. As discussed below, the NCLB data at the state level provides useful archival data on school performance.Transparency of information is also an important factor in school choice.

\section{The School Choice Movement}

The default arrangement in the United States is the school district, which administers all schools from kindergarten through 12th grade $(\mathrm{K}-12)$ within a given geographic area.A district is primarily funded from property taxes, which are based on the value of properties in the district, and these 
funds are supplemented from state and federal sources. A democratically elected school board typically governs the district with the day-to-day operation in the hands of a superintendent. Teachers in the public school system tend to be unionized and are often protected by tenure arrangements and other collective bargaining mechanisms, which some have argued act as a barrier to reform.

Students within the district are zoned to schools and typically have little say in the school they wish to attend. However, some competition exists even in the default system, as families are often willing to relocate to better school districts (Hoxby, 2003a). This has led to an escalation in housing prices in the better school districts and zones, often preventing less affluent families from accessing a quality education (Warren \& Tyagi, 2003). Coincidentally, this arrangement also provides a disincentive to establish private schools, as families are acutely aware that they are paying for the public system through their property taxes.

The concept of "school choice" lies at the heart of recent attempts to introduce more competition into the default public system and boost educational outcomes (Hoxby, 2003a). School choice is an umbrella term that encompasses a wide range of institutional arrangements, including open enrollment, vouchers, charter schools, and home schooling. For instance, open enrollment allows students to move to other schools within (intradistrict transfer) or outside their districts (Hoxby, 1998). A typical example would be the provision of a magnet school for talented students. In practice, when the demand for better schools exceeds the supply of seats, then districts are usually required to allocate places by lottery. This minimizes competitive pressures on underperforming schools. In addition, funding may not follow a student that moves outside the district. Voucher systems enable parents to "vote with their feet" and move their educational dollars to better, often private, schools (Friedman, 1955). In practice, voucher systems have been slow to gain acceptance, with Milwaukee generally credited as starting the first large-scale program in 1990.

According to the American Federation for Children (2012), only around 200,000 students in 16 states across the nation make use of a voucher or scholarship program (from a total school-age population of around 50 million). Home schooling, on the other hand, is legal in all 50 states and an estimated 1.5 million children are home schooled. Legal challenges to the use of voucher funds at religious (parochial) private schools, which represent 85 percent of private school enrollments, are one of the factors that have slowed the adoption rate of these programs, but a recent Supreme Court ruling has removed this restriction, and voucher programs are expected to grow in the future.

Charter schools, on the other hand, cater to around 1.7 million children in 41 states. The first charter school regula- tions were created in Minnesota in 1991. Regulations for charter schools vary by state, but generally a school receives a charter to operate independently from a school district while agreeing to meet state accountability requirements in exchange for public funds (often a combination of district rebates and state subsidies). A charter school then operates relatively independently of district curriculum and staffing policies with its own board of trustees. Some states also allow charter schools to be owned and operated by for-profit corporations. Most states require charter schools to adhere to state regulations on student testing and teacher licensing.

Extensive research has been conducted on whether charter schools improve the performance of their students (Bettinger, 2005; Ni, 2009; Teasley, 2009; Toma \& Zimmer, 2012). To date, panel studies of fixed effects show little difference in achievement between students at traditional public schools and charter schools (Teasley, 2009; Toma \& Zimmer, 2012). However, charter schools that are oversubscribed are required to choose their students by lottery. This creates a natural experiment between students who are admitted to a charter school and those who are not (Tuttle, Gleason, \& Clark, 2012). Lottery-based studies have found a positive performance effect for students attending charter schools from disadvantaged populations and urban areas (Hoxby \& Murarka, 2009) but negative effects have been found for those from suburban and more affluent populations (Gleason, Clark, Tuttle, \& Dwoyer, 2010). In all cases, there are significant variations in student achievement that are systematic and not purely random. Some schools are able to generate large performance gains while others are not. Researchers have been urged to investigate this "black box" of micro-level processes to understand these performance variations (Teasley, 2009).

\section{Entrepreneurial Orientation}

According to Teasley (2009), educational researchers " . . . rarely drill down into the areas of school organization, curriculum, instruction, and resources that are argued to provide the largest rationale [for school choice]" (p. 210). The observed heterogeneity in school performance is prima facie evidence that not all schools are equally efficient and effective at producing student achievement. While family background and student ability are important factors, variations in school operations are also believed to play a significant role in determining student outcomes. For instance, a recent study found charter schools were more efficient than traditional schools but also displayed a wider variance between best practice and average performance (Preston, Goldring, Berends, \& Cannata, 2012).

This is not surprising given the relative novelty of the charter form in the educational arena. The market process does not automatically produce best practice. Rather, these 
solutions evolve over time through a process of creative destruction that rewards successful adaptation, whether through innovation or rapid imitation, and punishes poor decisions through loss of market share and, ultimately, failure of the organization or even an organizational form. As the level of competition increases in public education, the need to innovate and absorb best practices will likely intensify. It is thus credible to expect that a school's EO will influence its performance.

EO is a firm-level construct that seeks to measure the degree of entrepreneurial behaviors and dispositions within an organization on a number of dimensions, including innovativeness, proactiveness, and risk-taking (Covin \& Slevin, 1991; Miller, 1983). EO represents how an organization is prepared to discover and exploit opportunities (Wiklund \& Shepherd, 2003). Moreover, the level of EO has been shown to predict organizational performance (Lumpkin \& Dess, 1996). This direct relationship has been shown to be moderated by a number of factors, including elements of the external environment (e.g., industry life cycle and dynamism) and internal factors (e.g., culture, firm size, structure, and strategy) (Becherer \& Maurer, 1997; Covin \& Slevin, 1991).

To date, more than 50 studies have empirically examined the EO-performance relationship in business organizations and a recent meta-analytic study has determined the existence of a moderate positive correlation between EO and financial performance in this population (Rauch, Wiklund, Lumpkin, \& Frese, 2009). The strength of the relationship appears to be moderated by industry type and firm size, with the effect being stronger for smaller firms in more dynamic industries, such as information technology. Interestingly, similarly strong correlations were found for different operationalizations of the EO construct and different measures of performance (financial vs. nonfinancial, archival vs. perceived). The relationship was also found to be equally significant across different countries.

Scholars have also started to consider the role of an EO in nonprofit organizations. Morris et al. (2011) document 10 EO-performance studies from a variety of nonprofit contexts dating back to 1995 . They make the salient point that the focus of a nonprofit lies in its social mission and that performance is seldom measured simply by financial indicators. As such, nonprofit studies have adapted the basic EO instrument to account for these differences in their mission. For instance, in a study of religious congregations, Pearce et al. (2010) found that EO predicted a composite performance measure of growth in attendance and giving over a threeyear period. A study by Eyal \& Inbar (2003) on the highly centralized Israeli school system found that schools in the periphery scored higher on principal proactivity and innovativeness, two measures influenced by the EO literature but not strictly derived from it. Moreover, while noticing variations in the level of entrepreneurial behavior by school type, Eyal \& Inbar (2003) were unable to link their instrument to measures of school performance. The accountability regime in the United States makes the study of this relationship easier to assess.

Debate has also raged over whether EO should be studied as a unidimensional measure or conceived along three to five independent dimensions (Covin \& Lumpkin, 2011). Miller (1983) initially outlined three dimensions to describe the entrepreneurial activity of a firm: innovation, proactiveness, and risk-taking. Two additional dimensions, competitive aggressiveness and autonomy, were added by Lumpkin \& Dess (1996). The current consensus seems to favor treating the EO scale in total with individual predictions for each dimension (Covin \& Lumpkin, 2011). As such, we develop hypotheses for EO and individual dimensions in the following section.

\section{Hypotheses}

A school with a strong EO has elected to adopt a strategic posture that provides a set of dispositions and behavioral repertoires that favor novel adaptations to environmental changes. Given that charter schools were explicitly created to compete with traditional public schools, we expect that their entrepreneurial orientations would be more pronounced on all dimensions. Therefore we propose

\section{H1. EO will be higher in charter schools than traditional public schools on all dimensions.}

The increased emphasis on school choice over the past 20 years has created an environment that is increasingly competitive and turbulent for public schools. Consistent with previous research that found that less munificent and more dynamic environments favor entrepreneurially minded firms (Rauch et al., 2009), we expect that

\section{H2. EO will be positively associated with school performance.}

Pearce et al. (2010) describe innovativeness as "an organization's willingness to support new ideas, novelty, and experimentation, and to depart from existing technologies and practices" (p. 225). There is no doubt that advocates of school choice expect increased competition to spur innovation and improve outcomes (Peterson, 2010). Other scholars have warned that choice and competition may lead either to conformity (Lubienski, 2003) or needless innovation for innovation's sake that might actually suppress performance (Preston, et al., 2012). Nevertheless, school choice initiatives have been developed with the belief that innovation can positively affect performance. 


\section{H3. Innovativeness will be positively associated with school performance.}

Proactiveness has been described as "the emphasis on being the first to take action" (Pearce et al., 2010, p. 226) and "the tendency of an organization to anticipate future wants and needs and to pursue change ahead of the competition" (Morris et al., 2011, p. 949). Proactiveness refers to all actions taken to maintain competitiveness, whether innovative or not.Thus, it includes not only experimenting with new ideas but actively seeking to incorporate best practices into a school.As such, we expect

\section{H4. Proactiveness will be positively associated with school performance.}

Risk-taking has been defined as "the willingness to commit significant resources to uncertain projects where outcomes are unknown and there is a potential for meaningful loss" (Morris et al., 2011, p. 949) and "the willingness to take risks, and to act outside of accepted practices and norms" (Pearce et al., 2010, p. 227). In the financial world, larger risks are often associated with larger rewards but also increased variation in performance, therefore

\section{H5. Risk-taking will be positively associated with school performance.}

Competitive aggressiveness "is a strategic behavior focused on expanding an organization's market share at the expense of competitors" (Pearce et al., 2010, p. 226). It is unclear how much individual principals consider themselves in a battle for market share with other local schools. However, studies of competition in education often use relative shares of a traditional, charter, and private schools as a proxy for the degree of competition suggesting, at the very least, implicit competition among organizational forms. Indeed, there is evidence to suggest increased competition on this level leads to higher student achievement scores (Hoxby, 2003b). Conceivably, schools that focus on matching or besting their competitors will be more driven to produce better results, therefore

\section{H6. Competitive aggressiveness will be positively associated with school performance.}

Autonomy "is the ability to take independent action that affects strategy" (Pearce et al., 2010, p. 227). In small organizations, it may mean becoming highly centralized under a focused leader, most likely the principal in a school. In larger organizations, autonomy often involves senior managers shielding innovators from organizational norms by bending the rules and bypassing procedures and budgets (Lumpkin \& Dess, 1996). School choice advocates see autonomy from centralized bureaucratic control as a key ingredient of innovation and improved outcomes (Chubb \& Moe, 1990). Therefore

\section{H7. Autonomy will be positively associated with school performance.}

\section{Control Variables}

Following Pearce et al. (2010), we collected data on a number of control variables in order to control for known (and unknown) sources of variation in school performance. These variables included school age, school size (number of students), tenure of principal, level of school, and proportion of disadvantaged students. We know from the Rauch et al. (2009) meta-analysis that larger and older organizations tend to have a lower EO.A lengthy tenure might also contribute to a less dynamic organization. Level of school refers to elementary (K-5), middle (6-8), and high schools (9-12). We had no specific expectations on the level of school although we suspected that high schools may have more financial resources and thus more flexibility to experiment. Finally, many educational outcomes in the United States depend on socioeconomic status. It is important that this variable is controlled in any analysis.

\section{Performance}

The federal NCLB statute requires students in every school receiving federal funding to undergo standardized testing at a state level in grades 3-8 and at least once in high school. This provides ample archival data for determining relative student achievement from schools across a given state. In the current study, we collected performance measures from the highest tested grade in a school (i.e., 5th grade for elementary schools, 8 th grade for middle schools, and 11th grade for high schools).

We were also interested in exploring intermediate performance variables that are known (or suspected) to influence student achievement, such as curricular innovations, teacher retention, extracurricular activities, and fund raising. By necessity, many of these performance variables were collected through self-report (although New Jersey schools also report the funding per pupil for extracurricular activities). Respondents were asked to rate their performance relative to peers in the district and state. We also asked for self-reported estimates on student achievement. Both Rauch et al. (2009) and Pearce et al. (2010) report similar correlations between EO and performance measures collected via self-report and archival sources.

\section{Data Collection and Methodology Sample}

The target population for the study was schools in the state of New Jersey. The New Jersey statute authorizing charter schools was passed in 1995 and implemented in 1996, just five years after the first program in the United States. As one of the largest teacher preparation and professional doctorate 
(EdD) programs in the state, it was thought that this name recognition would elicit participation in the study by principals and principal associations. Participants were contacted through their respective state organizations (e.g., the New Jersey Charter Schools Association, New Jersey Principal and Supervisor's Association, and New Jersey Association of Independent Schools). All three associations agreed to participate in the study.

\section{Procedure}

An email link to an electronic survey was emailed to all participants through their respective associations. The instrument contained three sections. The first section solicited common demographic items from the respondent, including his or her role in the organization, school level, type, name of school, years with organization, zip code, enrollment, and age of organization.

The second section solicited respondent impressions of their school's EO using a 7-item Likert scale. The EO instrument was adapted for education by the researchers using the religious organizations' EO instrument developed by Pearce, Fritz, and Davis (2010). Pearce et al. (2010) used three questions for each of the five EO subscales. The questions were modified slightly for the educational context. Several professors of education reviewed the survey instrument during its development and feedback was also sought from a number of principals and assistant principals taking EdD classes at our institution. The questions on the final survey are included in Appendix A.The third section of the survey asked respondents to use a 7-point scale to rate their school relative to other schools in their district and state on five measures: student achievement, teacher retention, innovative teaching methods, extracurricular offerings, and fund raising.

After the survey responses were received, additional data on school performance was collected from the New Jersey Department of Education's New Jersey School Report Card (New Jersey Department of Education, 2011). The report presents 35 fields of information for each school in the following categories: school environment, students, student performance indicators, staff, and district finances. The availability of this data enabled us to match respondent perceptions with archival data on performance on a number of dimensions, including math and language proficiency and extracurricular funding per student. We were also able to determine the percentage of disadvantaged students at a school and the proportion of the budget received from federal sources (a close proxy for disadvantage given targeted federal funding of disadvantaged schools).

\section{Results}

A total of 91 usable surveys were received-80 from public schools, 9 from charter schools, 1 from a private school, and 1 from a public magnet school. This translates into a response rate of 3.2 percent from public schools and 12 percent from charter schools. Private schools and magnet schools were excluded from subsequent analysis given the low response rate. Principals completed the majority of surveys (73\%) with the remaining surveys (27\%) being completed by assistant principals. More than half of the respondents were employed at elementary schools (52\%), with high schools (27\%), middle schools (17\%), and hybrids (4\%) making up the remaining responses.

\section{Aggregate Measures}

Two aggregate measures of EO were calculated. The EO3 measure was the sum of scores for the proactiveness, innovation, and risk-taking items, while EO5 added the autonomy and competitive aggressiveness items to the base EO3 measure. Cronbach's alpha was 0.88 for EO3 and 0.90 for EO5 with item-total correlations ranging from 0.86 to 0.90 . Although these scores may seem high, the mean inter-item correlation for the EO5 scale was just 0.38 suggesting good discrimination among the items.

On the performance side, the variable DP represented the sum of the relative district performance items, while SP was the sum of relative state performance items. Cronbach's alpha for the DP scale was 0.61 with a value of 0.72 for the SP scale. Item total correlations ranged from 0.50 to 0.61 for the DP scale and 0.63 to 0.75 for the SP scale. The SP scale displays an acceptable level of reliability that is slightly above the traditional cutoff of 0.70 , while the DP scale falls slightly below the cutoff.

The information in Table 1 displays the means, standard deviations, and correlations among the aggregate variables. The EO variables are highly correlated with strong correlations also evident between the two performance variables. The EO and performance variables were moderately correlated together.All correlations were significant at the $\mathrm{p}<0.01$ levels. Common methods bias is always a concern using similar methods to measure independent and dependent variables (Podsakoff, MacKenzie, Lee, \& Podsakoff, 2003). One test for this bias is to use a principal component analysis to see if the variables load

\begin{tabular}{|c|c|c|c|c|c|c|c|}
\hline \multicolumn{7}{|c|}{ Table 1. Correlations, Means, and Standard } \\
Deviations among Aggregate Variables \\
\hline & $N$ & Mean & Std Dev & EO5 & EO3 & DP & SP \\
\hline EO5 & 89 & 68.72 & 14.12 & 1.00 & 0.96 & 0.26 & 0.30 \\
\hline EO3 & 89 & 42.94 & 9.38 & 0.96 & 1.00 & 0.28 & 0.32 \\
\hline DP & 88 & 24.99 & 4.93 & 0.26 & 0.28 & 1.00 & 0.76 \\
\hline SP & 88 & 23.35 & 5.67 & 0.30 & 0.32 & 0.76 & 1.00 \\
\hline
\end{tabular}


highly on a common factor. The five EO subscales and 10 performance measures were entered into such an analysis and a two-factor varimax rotated solution was obtained.

The results indicated that the EO measures loaded predominantly on one factor while the performance measures loaded on a second factor (see Table 2 for rotated factor loadings). We concluded that common method bias was not apparent in the data.

\section{Archival Data}

For each school, we captured the proportion of students who were proficient or above proficient in language and math on either the High School Proficiency Assessment (for 11th Grade) or New Jersey Assessment of Skills and Knowledge (at 5th grade for elementary schools and 8th grade for middle schools). Data were available for 72 of the 89 schools in the sample. The report card also provided the proportion of disadvantaged students taking the assessment at each school but data were only available for 49 schools. Luckily, the proportion of disadvantaged students was highly correlated $(r=0.77, p<0.001)$ with the percentage of total school budget received from federal sources. Data were avail-

\begin{tabular}{|c|c|c|}
\hline \multicolumn{3}{|c|}{$\begin{array}{c}\text { Table 2. Rotated Factor Loadings of } \\
\text { Aggregate Variables }\end{array}$} \\
\hline & Factor 1 & Factor 2 \\
\hline \multicolumn{3}{|l|}{ EO Subscales } \\
\hline Innovativeness & 0.81 & 0.09 \\
\hline Proactiveness & 0.80 & 0.19 \\
\hline Risk-taking & 0.81 & -0.11 \\
\hline Competitiveness & 0.64 & -0.24 \\
\hline Autonomy & 0.64 & 0.21 \\
\hline \multicolumn{3}{|l|}{ District } \\
\hline Student Achievement & 0.14 & 0.51 \\
\hline Teacher Retention & 0.24 & 0.62 \\
\hline Curriculum Innovation & 0.70 & 0.39 \\
\hline Extracurricular Activities & 0.05 & 0.36 \\
\hline Funding & -0.22 & 0.58 \\
\hline \multicolumn{3}{|l|}{ State } \\
\hline Student Achievement & 0.14 & 0.67 \\
\hline Teacher Retention & 0.29 & 0.74 \\
\hline Curriculum Innovation & 0.69 & 0.47 \\
\hline Extracurricular Activities & 0.06 & 0.34 \\
\hline Funding & -0.12 & 0.66 \\
\hline
\end{tabular}

able for 79 schools on this measure and this proxy was substituted for disadvantage in multivariate analysis.Additionally, we were able to determine the per capita spending on extracurricular activities for 79 schools. Table 3 details the basic statistics for the archival measures including means and correlations with self-reported aggregate data. The four archival measures all exhibited a degree of skewness that was corrected using logarithmic transformations.

\section{Differences in EO between Traditional and Charter Schools}

A number of t-tests for unequal variances were conducted to test the hypothesis that charter schools scored higher on EO and its components than traditional public schools. The results of these analyses are presented in Table 4 and show that charter schools scored significantly higher than traditional schools on all measures except innovativeness. These results tend to support hypothesis 1 although it was surprising that innovativeness was not significant given the importance that school choice advocates place on this dimension.

\begin{tabular}{|c|c|c|c|c|}
\hline \multicolumn{5}{|c|}{$\begin{array}{l}\text { Table 3. Descriptive Statistics and Correlations } \\
\text { for Archival Data }\end{array}$} \\
\hline Variable & Language & Matb & Fed Rev & Extra \\
\hline $\mathbf{N}$ & 72 & 72 & 79 & 79 \\
\hline Mean & 0.76 & 0.72 & 0.03 & 303.01 \\
\hline $\begin{array}{l}\text { Standard } \\
\text { Deviation }\end{array}$ & 0.19 & 0.19 & 0.03 & 225.78 \\
\hline Min & 0.13 & 0.13 & 0 & 0 \\
\hline Max & 1 & & & \\
\hline $\begin{array}{l}\text { Language } \\
\text { Proficiency }\end{array}$ & 1.00 & & & \\
\hline Math Proficiency & 0.59 & 1.00 & & \\
\hline Federal Revenue & -0.60 & -0.79 & 1.00 & \\
\hline $\begin{array}{l}\text { Extracurricular } \\
\text { Funding per } \\
\text { Capita }\end{array}$ & 0.53 & 0.37 & -0.39 & 1.00 \\
\hline EO3 & -0.04 & 0.00 & 0.12 & 0.09 \\
\hline EO5 & -0.02 & -0.03 & 0.14 & 0.03 \\
\hline $\begin{array}{l}\text { Relative District } \\
\text { Performance }\end{array}$ & 0.39 & 0.32 & -0.21 & 0.22 \\
\hline $\begin{array}{l}\text { Relative State } \\
\text { Performance }\end{array}$ & 0.42 & 0.43 & -0.30 & 0.27 \\
\hline
\end{tabular}

Note: If $|\mathrm{r}|>0.20$, then $\mathrm{p}<0.05$ 


\section{The EO-Performance Relationship}

A series of regression models were constructed to explore the EO-performance relationship in our data.The base model included a set of control variables (school size, school age, principal tenure) that closely match those used on a previous study of religious congregations (Pearce, et al., 2010). Again, following Pearce et al. (2010), we constructed a composite measure of performance based on self-reported and archival data using a principal components analysis. The first principal component explained 36 percent of the variance in performance, with 12 of the 13 measures having factor loadings between 0.52 and 0.75 . Extracurricular funding per student only loaded 0.34 and was subsequently dropped from the composite score. The average factor loading for the remaining 12 variables was 0.61 .

Four distinct models were created (see Table 5). The first model contained a series of control variables, including title of respondent, level of school, type of school, age of school, number of students, tenure of respondent, and degree of disadvantage (measured by proportion of district funds from federal sources). The control model was able to explain almost half of the variance in the sample with disadvantage being the dominant explanatory variable. The second model added $\mathrm{EO}$ (EO5) into the regression model. EO was significant at the $p<0.01$ level and explained an additional 6 percent of the variance thus supporting hypothesis 2 .The third model is actually a set of models that iteratively adds each of the dimensions of EO to the regression model. The most significant variable is proactiveness but innovativeness and autonomy are also significant supporting hypotheses 3,4 , and 7 .

Risk-taking and competitive aggressiveness failed to reach significance so hypotheses 5 and 6 were not supported. Entering proactiveness instead of EO explained 8 percent more of the variance than the control model, slightly more than $\mathrm{EO}$ as an aggregate construct.

The final model uses a stepwise approach to select only a

\begin{tabular}{|l|r|l|}
\hline \multicolumn{3}{|c|}{$\begin{array}{r}\text { Table 4. Differences in EO between Traditional } \\
\text { and Charter Schools }\end{array}$} \\
\hline Variable & 1.29 & n.s. \\
\hline Innovativeness & 2.26 & $*$ \\
\hline Proactiveness & 2.89 & $* *$ \\
\hline Risk-Taking & 2.28 & $*$ \\
\hline Competitive Aggressiveness & 3.05 & $* *$ \\
\hline Autonomy & 2.84 & $* *$ \\
\hline EO3 & 2.36 & $*$ \\
\hline EO5 & & \\
\hline
\end{tabular}

${ }^{*}-\mathrm{p}<0.05,{ }^{* *}-\mathrm{p}<0.01$ small subset of the variables that explain the most variance. Using this approach, disadvantage and proactiveness emerged as the most significant variables. Schools with principals with longer tenure performed better as did high schools over elementary and middle schools. The stepwise model is able to explain 52 percent of the variance with only four variables thus yielding a very strong $\mathrm{F}$ statistic for the model of 17.72 .

\section{Conclusion and Implications}

The results indicate that aspects of entrepreneurial orientation, specifically proactiveness, innovativeness, and autonomy, were significantly associated with the performance in the sample of New Jersey schools that responded to our survey. Charter schools were also found to have a significantly high-

\begin{tabular}{|c|c|c|c|c|}
\hline \multicolumn{5}{|c|}{$\begin{array}{c}\text { Table 5. Results of Regression Analysis: EO } \\
\text { and Performance }\end{array}$} \\
\hline $\begin{array}{l}\text { Dependent } \\
\text { Variable }\end{array}$ & Model 1 & Model 2 & Model 3 & Model 4 \\
\hline $\begin{array}{l}\text { Composite } \\
\text { Performance }\end{array}$ & Control & $\mathrm{EO}$ & Dimensions & Stepwise \\
\hline \multicolumn{5}{|l|}{ Controls } \\
\hline Title & 0.02 & 0.02 & & \\
\hline Level & -0.15 & -0.13 & & $-0.19^{*}$ \\
\hline Type & 0.11 & 0.04 & & \\
\hline Tenure & $0.24^{*}$ & $0.21^{*}$ & & $0.21^{*}$ \\
\hline $\begin{array}{l}\text { Number of } \\
\text { Students }\end{array}$ & 0.04 & 0.1 & & \\
\hline School Age & 0.04 & -0.01 & & \\
\hline Disadvantage & $-0.60^{* * *}$ & $-0.58^{* *}$ & & $-0.56^{* * *}$ \\
\hline \multicolumn{5}{|l|}{$\begin{array}{l}\text { Independent } \\
\text { Variables }\end{array}$} \\
\hline EO & & $0.26^{* *}$ & & \\
\hline Innovativeness & & & $0.21^{*}$ & \\
\hline Risk-taking & & & 0.15 & \\
\hline Proactiveness & & & $0.31 * *$ & $0.28^{* *}$ \\
\hline Competitiveness & & & 0.07 & \\
\hline Autonomy & & & $0.27^{* * *}$ & \\
\hline Model R2 & 0.45 & 0.51 & 0.53 & 0.52 \\
\hline Adj. R2 & 0.37 & 0.43 & 0.45 & 0.49 \\
\hline Model F & $5.38^{* * *}$ & $6.06^{* *}$ & $6.65^{\text {*** }}$ & $17.72^{* * *}$ \\
\hline
\end{tabular}

$\mathrm{N}=69,{ }^{*} \mathrm{p}<0.05,{ }^{* *}-\mathrm{p}<0.01$

Standardized regression coefficients are reported. 
er EO than traditional schools on all dimensions except innovativeness. The results seem to indicate that $\mathrm{EO}$ is a useful construct for understanding performance heterogeneity between schools, explaining 6 percent to 8 percent of the variance in our sample. Our modified EO instrument for schools also worked well with a high level of reliability among items and moderate correlations between the underlying dimensions.

These performance gains are evident for all schools with an entrepreneurial orientation. That is, charter schools do not perform better than traditional schools in the aggregate. This lends support to Teasley's (2009) argument that understanding the processes within a school is critical to understanding performance differentials. One does not have to be a charter school to realize performance gains through EO although charter schools as a class tend to be better placed to act entrepreneurially. This reinforces the view that charter schools are not all equally efficient. Schools can improve their performance and more entrepreneurial schools appear to be doing just that.

In fact, the results seem to indicate the developing a culture of proactiveness would be the single most important thing a school could do. However, innovativeness and autonomy seem to covary with proactiveness. In other words, these traits seem to arise in a cluster or configuration that is inde- pendent of risk-taking or competitiveness. It is hard to determine if one aspect precedes another. For instance, does autonomy allow schools to be more innovative and proactive? Further research is needed to delve into the mechanisms underlying this effect. Similarly, understanding why risk-taking and competitive aggressiveness have decoupled from other parts of EO in this context is also worth exploring.

Of course, the focus on one state and relatively low response rate (there are 2,500 public schools in New Jersey and almost 100,000 schools in the United States) means that it is difficult to generalize our results to entire populations. However, the authors are working to expand the sample to other states and nations to explore the effect of different institutional contexts on the EO-performance relationship. If the previous work on EO is any guide, the results are likely to persist across geographic boundaries and variations in institutional context.

In conclusion, this study provides support for the contention that EO is a useful construct for understanding variations in school performance. For educational theory, it helps to explore inside the "black box" of school practice that has often eluded educational researchers. For entrepreneurship theory, it helps to confirm the notion that EO is a construct that transcends the world of business and allows us to explore the effects of entrepreneurial behavior in new ways.

\section{References}

American Federation for Children. (2012). Facts. Retrieved July 12, 2012, from http://www.federationforchildren.org/facts

Ball, S. J. (1998). Big Policies/Small World:An Introduction to International Perspectives in Education Policy. Comparative Education, 34(2), 119-130. doi: 10.1080/03050069828225

Becherer, R. C., \& Maurer, J. G. (1997). The Moderating Effect of Environmental Variables on the Entrepreneurial and Marketing Orientation of Entrepreneur-led Firms. Entrepreneurship Theory and Practice, 22(1), 47.

Bettinger, E. P. (2005). The Effect of Charter Schools on Charter Students and Public Schools. Economics of Education Review, 24(2), 133-147. doi: 10.1016/j.econedurev.2004.04.009

Bhuian, S. N., Menguc, B., \& Bell, S. J. (2005). Just Entrepreneurial Enough:The Moderating Effect of Entrepreneurship on the Relationship between Market Orientation and Performance. Journal of Business Research, 58(1), 9-17. doi: 10.1016/s0148-2963(03)00074-2

Burch, P. (2009). Hidden Markets: The New Education Privatization. New York: Routledge.

Chubb, J. E., \& Moe, T. M. (1990). Politics, Markets, and America's Schools: Brookings Institution Press.

Covin, J. G., \& Lumpkin, G.T. (2011). Entrepreneurial Orientation Theory and Research: Reflections on a Needed Construct. Entrepreneurship:Theory \& Practice, 35(5), 855-872. doi: 10.1111/j.1540-6520.2011.00482.x

Covin, J. G., \& Slevin, D. P. (1991).A Conceptual Model of Entrepreneurship As Firm Behavior. Entrepreneurship Theory E Practice, 16(1), 7-25.

Eyal, O., \& Inbar, D. E. (2003). Developing a Public School Entrepreneurship Inventory. International Journal of Entrepreneurial Behaviour \& Research, 9(6), 221-244. doi: 10.1108/13552550310501356

Friedman, M. (1955). The Role of Government in Education. In R.A. Solo (Ed.), Economics and the Public Interest (pp. 85-107). New Brunswick, NJ: Rutgers University Press.

Gleason, P., Clark, M., Tuttle, C. C., \& Dwoyer, E. (2010). The Evaluation of Charter School Impacts: Final Report. NCEE 20104029. National Center for Education Evaluation and Regional Assistance, 259. 
Hoxby, C. M. (1998). What Do America's “Traditional” Forms of School Choice Teach Us about School Choice Reforms? Economic Policy Review-Federal Reserve Bank of New York, 4(1), 47-59.

Hoxby, C. M. (2003a). The Economics of School Choice. Chicago: University of Chicago Press.

Hoxby, C. M. (2003b). School Choice and School Competition: Evidence from the United States. Swedish Economic Policy Review, 10(2), 9-66.

Hoxby, C. M., \& Murarka, S. (2009). Charter Schools in New York City: Who Enrolls and How They Affect Their Students' Achievement: National Bureau of Economic Research.

Lubienski, C. (2003). Innovation in Education Markets:Theory and Evidence on the Impact of Competition and Choice in Charter Schools. American Educational Research Journal, 40(2), 395-443. doi: 10.3102/00028312040002395

Lubienski, C. (2005). Public Schools in Marketized Environments: Shifting Incentives and Unintended Consequences of Competition-Based Educational Reforms. American Journal of Education, 111(4), 464-486. doi: 10.1086/431180

Lumpkin, G.T., \& Dess, G. G. (1996). Clarifying the Entrepreneurial Orientation Construct and Linking It to Performance. Academy of Management Review, 21(1), 135-172.

Miller, D. (1983). The Correlates of Entrepreneurship in Three Types of Firms. Management Science, 29(7), 770-791. doi: $10.1287 /$ mnsc. 29.7 .770

Morris, M. H., Webb, J.W., \& Franklin, R. J. (2011). Understanding the Manifestation of Entrepreneurial Orientation in the Nonprofit Context. Entrepreneurship Theory and Practice, 35(5), 947-971. doi: 10.1111/j.1540-6520.2011.00453.x

National Commission on Excellence in Education. (1983). A Nation at Risk:The Imperative for Educational Reform: Federal Department of Education.

New Jersey Department of Education. (2011). 2011 New Jersey School Report Card. Retrieved May 5, 2012, from http:// education.state.nj.us/rc/

Ni,Y. (2009). The Impact of Charter Schools on the Efficiency of Traditional Public Schools: Evidence from Michigan. Economics of Education Review, 28(5), 571-584. doi: 10.1016/j.econedurev.2009.01.003

Pearce, J.A., Fritz, D. A., \& Davis, P. S. (2010). Entrepreneurial Orientation and the Performance of Religious Congregations as Predicted by Rational Choice Theory. Entrepreneurship Theory and Practice, 34(1), 219-248. doi: 10.1111/j.15406520.2009.00315.x

Peterson, P. E. (2010). Competition and Charters Spur Innovation: School Markets Are Creative, Not Static. Education Next, $10(3), 5$.

Podsakoff, P. M., MacKenzie, S. B., Lee, J.Y., \& Podsakoff, N. P. (2003). Common Method Biases in Behavioral Research:A Critical Review of the Literature and Recommended Remedies. Journal of Applied Psychology, 88(5), 879.

Power, S., \& Frandji, D. (2010). Education Markets, the New Politics of Recognition and the Increasing Fatalism towards Inequality. Journal of Education Policy, 25(3), 385-396. doi: 10.1080/02680930903576404

Preston, C., Goldring, E., Berends, M., \& Cannata, M. (2012). School Innovation in District Context: Comparing Traditional Public Schools and Charter Schools. Economics of Education Review, 31(2), 318-330. doi: 10.1016/j.econedurev.2011.07.016

Rauch,A., Wiklund, J., Lumpkin, G.T., \& Frese, M. (2009). Entrepreneurial Orientation and Business Performance: An Assessment of Past Research and Suggestions for the Future. Entrepreneurship Theory and Practice, 33(3), 761-787.

Teasley, B. (2009). Charter School Outcomes. In M. Berends, M. G. Springer, D. Ballou \& H. J. Walberg (Eds.), Handbook of Research on School Choice (pp. 209-225). New York: Routledge.

Toma, E., \& Zimmer, R. (2012). Two Decades of Charter Schools: Expectations, Reality, and the Future. Economics of Education Review, 31(2), 209-212. doi: 10.1016/j.econedurev.2011.10.001

Tuttle, C. C., Gleason, P., \& Clark, M. (2012). Using Lotteries to Evaluate Schools of Choice: Evidence from a National Study of Charter Schools. Economics of Education Review, 31(2), 237-253. doi: 10.1016/j.econedurev.2011.07.002

Warren, E., \& Tyagi, A. W. (2003). The Two-Income Trap: Why Middle-Class Mothers and Fathers Are Going Broke: Basic Books.

Wiklund, J., \& Shepherd, D. (2003). Knowledge-Based Resources, Entrepreneurial Orientation, and the Performance of Small and Medium-Sized Businesses. Strategic Management Journal, 24(13), 1307-1314. doi: 10.1002/smj.360 


\section{Appendix A. School Entrepreneurial Orientation Survey}

Answer all questions based on your impression of the school during the previous three years

Instructions: Please select a single number to indicate which of the two statements is most true for your school. Selecting a one (1) indicates strong agreement with the first statement, while a seven (7) indicates a strong agreement with the second statement, and a four (4) indicates both are equally true. The numbers in between represent differing degrees of agreement with one of the two statements.

\begin{tabular}{|l|l|l|l|l|l|r|r|}
\hline & $\begin{array}{l}\text { First statement } \\
\text { more true }\end{array}$ & \multicolumn{3}{c|}{ Equally True } & $\begin{array}{r}\text { Second statement } \\
\text { more true }\end{array}$ \\
\hline
\end{tabular}

(Innovativeness) I1 In general, the leadership in our school favors. . .

A strong emphasis on tried and true teaching

methods/techniques and extracurricular programs
A strong emphasis on new and innovative teaching methods/techniques and extracurricular programs

(Innovativeness) I2 How many new activities, teaching methods/techniques, or extracurricular programs has your school offered in the last 3 years?

\begin{tabular}{|l|l|l|l|}
\hline & Very many & & \\
\hline
\end{tabular}

(Innovativeness) I3 At my school ...

\begin{tabular}{|l|l|r|}
\hline $\begin{array}{l}\text { Changes in activities, teaching methods/techniques, and } \\
\text { extracurricular programshave been mostly of a minor nature }\end{array}$ & $\begin{array}{r}\text { Changes in activities, teaching } \\
\text { methods/techniques, and extracurricular } \\
\text { programs have been quite dramatic. }\end{array}$ \\
\hline
\end{tabular}

(Proactiveness) P1 My school ...

\begin{tabular}{|l|l|r|r|}
\hline $\begin{array}{l}\text { Is very seldom the first school to introduce new } \\
\text { policies and practices }\end{array}$ & $\begin{array}{r}\text { Is very often the first school to introduce } \\
\text { new policies and practices }\end{array}$ \\
\hline
\end{tabular}

(Proactiveness) P2 My school ...

\begin{tabular}{|l|l|r|r|}
\hline & We position ourselves to meet existing demands & $\begin{array}{r}\text { We position ourselves to meet } \\
\text { emerging demands }\end{array}$ \\
\hline
\end{tabular}

(Proactiveness) P3 My school ...

\begin{tabular}{|l|l|r|r|}
\hline $\begin{array}{l}\text { We rarely make changes due to perceived changes } \\
\text { occurring in the community }\end{array}$ & $\begin{array}{r}\text { We continually make changes due to } \\
\text { perceived changes occurring in the } \\
\text { community }\end{array}$ \\
\hline
\end{tabular}

(Risk-taking) RT1 In general, the leadership of my school has . . .

\begin{tabular}{|l|l|r|}
\hline $\begin{array}{l}\text { A strong tendency to adopt low-risk teaching methods/ } \\
\text { techniques and extracurricular programs with normal and } \\
\text { certain results }\end{array}$ & $\begin{array}{r}\text { A strong tendency to adopt high risk } \\
\text { teaching methods/techniques and } \\
\text { extracurricular programs with chances } \\
\text { of very dramatic results }\end{array}$ \\
\hline
\end{tabular}


continued

(Risk-taking) RT2 In general, the leadership of my school believes that ...

\begin{tabular}{|l|l|r|r|}
\hline $\begin{array}{l}\text { Owing to the nature of the environment, it is best to explore } \\
\text { changes gradually via cautious incremental } \\
\text { behavior }\end{array}$ & $\begin{array}{r}\text { Owing to the nature of the environment bold } \\
\text { wide ranging acts are necessary to achieve the } \\
\text { school's objectives }\end{array}$ \\
\hline
\end{tabular}

(Risk-taking) RT3 When confronted with the decision making situations involving uncertainty, our school . . .

\begin{tabular}{|l|l|r|r|}
\hline $\begin{array}{l}\text { Typically adopts a cautious, wait-and-see posture in order to } \\
\text { minimize the probability of making costly decisions }\end{array}$ & $\begin{array}{r}\text { Typically adopts a bold aggressive posture in } \\
\text { order to maximize the probability of exploiting } \\
\text { potential opportunities }\end{array}$ \\
\hline
\end{tabular}

(Competitiveness) C1 In dealing with other schools, my school ...

\begin{tabular}{|l|l|l|r|}
\hline $\begin{array}{l}\text { Rarely responds to changes and actions that other } \\
\text { schools initiate }\end{array}$ & $\begin{array}{r}\text { Always responds to changes and actions that } \\
\text { other schools initiate }\end{array}$ \\
\hline
\end{tabular}

(Competitiveness) C2 When dealing with other schools, my school ...

\begin{tabular}{|l|l|l|r|}
\hline $\begin{array}{l}\text { Typically seeks to avoid competitive clashes with } \\
\text { other schools }\end{array}$ & $\begin{array}{r}\text { Typically adopts a very competitive strategy } \\
\text { toward other schools }\end{array}$ \\
\hline
\end{tabular}

(Competitiveness) C3 At my school ...

\begin{tabular}{|l|l|l|r|}
\hline $\begin{array}{l}\text { Our actions toward other schools can be termed } \\
\text { accommodating }\end{array}$ & $\begin{array}{r}\text { Our actions toward other schools can be } \\
\text { termed aggressive }\end{array}$ \\
\hline
\end{tabular}

(Autonomy) A1 At my school ...

\begin{tabular}{|l|l|l|r|}
\hline $\begin{array}{l}\text { Very many changes suggested by teachers, board members, } \\
\text { or parents are implemented }\end{array}$ & $\begin{array}{r}\text { Very few changes suggested by teachers, board } \\
\text { members, or parents are implemented }\end{array}$ \\
\hline
\end{tabular}

(Autonomy) A2 At my school ...

\begin{tabular}{|c|c|}
\hline $\begin{array}{l}\text { Identifying new school activities, teaching methods/tech- } \\
\text { niques, and extracurricular programs is the responsibility of a } \\
\text { small number of individuals }\end{array}$ & $\begin{array}{r}\text { Identifying new school activities, teaching } \\
\text { methods/techniques, and extracurricular } \\
\text { programs is done by all members, including teach- } \\
\text { ers, board members, and parents }\end{array}$ \\
\hline
\end{tabular}

(Autonomy) A3 My school ...

\begin{tabular}{|l|l|r|r|}
\hline $\begin{array}{l}\text { Discourages independent activity to develop new teaching } \\
\text { methods/techniques and extracurricular programs }\end{array}$ & $\begin{array}{r}\text { Encourages independent activity to develop } \\
\text { new teaching methods/techniques and } \\
\text { extracurricular programs. }\end{array}$ \\
\hline
\end{tabular}




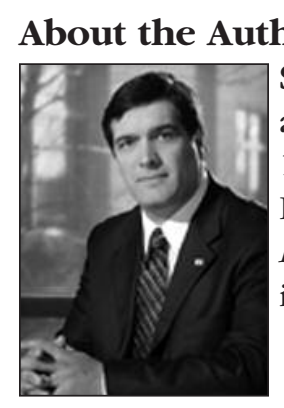

\section{MEj̉E}

Steven E. Phelan (sphelan@uncfsu.edu) holds the position of Distinguished Professor of Entrepreneurship at Fayetteville State University in North Carolina. He received his Ph.D. from La Trobe University (Australia) in 1998 and has previously held tenure track positions at the University of Texas at Dallas, the University of Nevada Las Vegas, and Rowan University. He was also the founding editor of the Strategic Management Review and creator of the Southern Nevada Business Plan Competition. His research broadly focuses on the issue of organizational performance-understanding it, measuring it, and improving it.

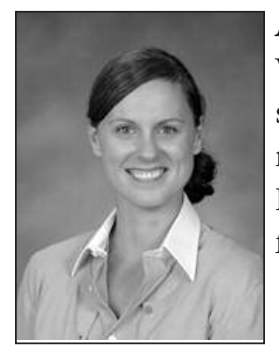

ANE T. Johnson (johnsona@rowan.edu) received her Ph.D. in Educational Leadership and Policy Studies from Virginia Polytechnic Institute and State University (Virginia Tech) in 2009. She joined the faculty at Rowan the same year. Dr. Johnson has published and presented on higher education policy and reform in emerging nations, university peacebuilding and development in Africa, and African women in university administration. Her research focuses on neoliberal policy mechanisms in education, international higher education policy, conflict and peacebuilding in higher education, and qualitative research methods.

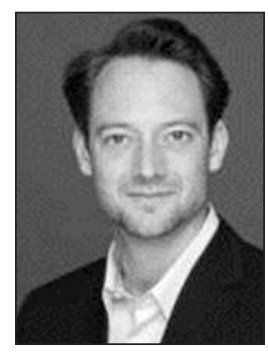

Thorsten SemraU (semrau@wiso.uni-koeln.de) acts as Ernst \& Young Endowed Assistant Professor for Business Administration and Corporate Development at the University of Cologne. His research interests lie in the fields of innovation management and learning, new venture creation and development, and networks and interorganizational relationships. From February to April 2011 he was a visiting scholar at the Center for Innovation and Entrepreneurship at Rowan University. 